This item was submitted to Loughborough's Research Repository by the author.

Items in Figshare are protected by copyright, with all rights reserved, unless otherwise indicated.

\title{
Political theory and history: The case of anarchism
}

PLEASE CITE THE PUBLISHED VERSION

http://dx.doi.org/10.1080/13569317.2015.1075263

\section{PUBLISHER}

(c) Taylor \& Francis

\section{VERSION}

AM (Accepted Manuscript)

\section{PUBLISHER STATEMENT}

This work is made available according to the conditions of the Creative Commons Attribution-NonCommercialNoDerivatives 4.0 International (CC BY-NC-ND 4.0) licence. Full details of this licence are available at: https://creativecommons.org/licenses/by-nc-nd/4.0/

\section{LICENCE}

CC BY-NC-ND 4.0

\section{REPOSITORY RECORD}

Adams, Matthew S., and Nathan J. Jun. 2019. "Political Theory and History: The Case of Anarchism". figshare. https://hdl.handle.net/2134/22104. 


\begin{abstract}
This essay critically examines one of the dominant tendencies in recent theoretical discussions of anarchism, postanarchism, and argues that this tradition fails to engage sufficiently with anarchism's history. Through an examination of late nineteenth-century anarchist political thought - as represented by one of its foremost exponents, Peter Kropotkin — we demonstrate the extent to which postanarchism has tended to oversimplify and misrepresent the historical tradition of anarchism. The article concludes by arguing that all political-theoretical discussions of anarchism going forward should begin with a fresh appraisal of the actual content of anarchist political thought, based on a rigorous analysis of its political, social, and cultural history.
\end{abstract}

\title{
Keywords
}

Anarchism; postanarchism; political theory; history of ideas; Peter Kropotkin; history 


\section{(Or, Prolegomena to Any Future Anarchist Political Theory)}

\section{Introduction}

In reflecting on the history of political philosophy in the twentieth century, it is notable that most of the individuals regarded as 'great thinkers' - Jean-Paul Sartre, Simone de Beauvoir, Max Horkheimer, Theodor Adorno, Michel Foucault, Gilles Deleuze, Hannah Arendt, Leo Strauss, Friedrich Hayek, Isaiah Berlin, John Rawls, Robert Nozick, etc.—were academics or, at the very least, recipients of advanced academic degrees. Although some of these thinkers, like Sartre and Foucault, were activists who wrote in the context of real-world political struggles, the larger share directed their work principally to the attention of their peers, that is, intellectuals and academics. By way of contrast, very few of the so-called 'canonical' thinkers of the classical anarchist movement, to say nothing of the thousands of anonymous individuals who participated in that movement, were college-educated, and next to none of them had advanced degrees or worked in universities. Many-like Pierre-Joseph Proudhon, Emma Goldman, and Errico Malatesta — were autodidacts who would have considered themselves revolutionaries rather than intellectuals. Notwithstanding the polemics of Lenin and other Marxists, who frequently accused anarchists of being counterrevolutionaries and members of the 'petty bourgeoisie', ${ }^{1}$ most anarchist writings were not intended solely, or even principally, for middle-class intellectuals, and certainly not for academics; rather, they were addressed to the struggling masses and, more generally, to the persuadable reading public for the sake of advancing the revolutionary cause.

All of this may help to explain why anarchism has mostly been ignored or dismissed outright by political theorists and historians of philosophy. Because the 'canonical' writings of Proudhon, Mikhail Bakunin, Peter Kropotkin, and many others besides did not generally take the form of philosophical tomes, let alone peer-reviewed academic monographs, ${ }^{2}$ there has surely 
been a tendency to dismiss them as mere 'propaganda' unworthy of serious consideration. The assumption being, which is obviously a product of the worst kind of intellectual snobbery and academic prejudice, is that credible political philosophy only emerges in elite institutional contexts. Pamphlets, tracts, editorials in revolutionary newspapers-these are not appropriate venues within which to articulate and defend serious philosophical ideas, or so it is implied.

Meanwhile the comparatively few scholars who have published significant historical and political-theoretical studies of anarchism have consistently represented anarchism as a single, uniform system of political thought knitted together piecemeal from the writings of a handful of 'canonical' anarchist writers from the nineteenth century—most notably Proudhon, Bakunin, and Kropotkin. In this, they have merely followed a longstanding convention in the discipline of intellectual history, and especially in the history of philosophy, according to which comprehensive, self-contained systems of thought and practice are derived from the disparate writings of 'great thinkers'. ${ }^{3}$ Although some political theorists and historians of political ideologies have grown increasingly skeptical of this narrow focus and have attempted to adopt a broader, more historically-informed approach in their own work, the study of anarchism has generally remained impervious to these methodological changes. ${ }^{4}$ The 'canonical approach' continues to reign supreme, the problem being that, at least in the case of anarchism, this fails to take into account the broader social, political, and cultural history of the anarchist movement and, by extension, the wide variety of sources, printed or otherwise, through which anarchist ideas were developed and disseminated. ${ }^{5}$

It should be emphasised that close readings of 'canonical' texts are not entirely without merit, provided that they are carried out with a finely-tuned sensitivity to the various contextshistorical, political, social, cultural, etc.-within which these texts emerged. Ideally, such 
exercises will be one component of a much more comprehensive strategy. Although anarchism can and should be examined as a form of political theory_or, more precisely, as a politicaltheoretical tradition or orientation-anarchism is not and has never been merely a form of political theory. Rather, anarchism is a complex and dynamic social, political, and cultural movement whose history cannot be ascertained by studying the canon alone. Instead, it must be understood in light of the fullest possible range of anarchist ideas and practices reflected in the political and social history of anarchism, including, but not limited to, transnational anarchist print culture.

Saul Newman, Todd May, and other postanarchist writers ${ }^{6}$ have been taken to task many times over for their failure to engage sufficiently with this complex anarchist history. ${ }^{7}$ Although postanarchism is not the only political theoretical-tendency susceptible to this accusation, ${ }^{8}$ it is arguably the most influential and widely discussed, ${ }^{9}$ and for this reason deserves special attention. In our view, existing criticisms of postanarchism do not go far enough. The problem is not just that postanarchist theory relies inordinately on a small and unrepresentative group of thinkers, or that it imputes views to these thinkers which they did not actually hold, but that it lacks an adequate understanding of the wider intellectual and political context within which they were operating, and to which they were responding. Through an examination of the thought of Kropotkin, one of the foremost exponents of late nineteenth-century anarchism, we will demonstrate the extent to which the failure to read classical anarchism contextually produces significant distortions, oversimplifications, and misrepresentations. In doing so, we offer an initial invitation to political theorists—including, but not limited to, postanarchists—-to begin a fresh appraisal of anarchist political thought based on a more careful and rigorous analysis of its history. 


\section{Anarchism, Ideology and Theory}

As countless writers have noted, anarchism is not a comprehensive, uniform, self-contained political philosophy, ideology, or system of thought. On the contrary, anarchist theory, to say nothing of anarchist practice, has always been marked by incredible diversity—so much, in fact, that it is difficult if not altogether impossible to provide a single definition of anarchism that applies with equal accuracy to all anarchists. A more helpful approach is offered by Michael Freeden, who has argued at length that political ideologies should not be viewed as fixed, invariable 'belief systems' so much as languages whose core concepts evolve and change over time. Freeden writes:

As products, both political philosophy and ideology are genres of political thought that display strong similarities in their morphology and that may overlap considerably in many of their normative and recommendatory features... Traditionally, the exploration of political thought has been organized around the persons who have best expressed coherent political thinking, around the main overarching themes with which it has been concerned, around the formulation of philosophically valid political utterances, or around particular historical periods. But the basic units of thinking about politics are the concepts that constitute its main foci, just as words are the basic units of language, and... the argument is put forward that the analysis of political thought, as a scholarly enterprise related to the methodological interests of students of social phenomena, is most usefully promoted by proceeding from the conceptual morphologies it displays. ${ }^{10}$

Freeden's suggestion is that otherwise distinct political traditions may be seen as bearing a 'family resemblance' to one another insofar as they share a kind of 'DNA' - that is, core concepts-in common. For example, if both John Locke and Rawls can be meaningfully described as 'liberals', it is not because they subscribe to a common belief system, but because their theories share certain core concepts. We can make the same point about different kinds of anarchists: They are 'anarchists' because they belong to the same philosophical 'family'. 
The difficulty comes in figuring out how the political-theoretical 'DNA' of the anarchist family is structured. As we noted in the introduction, the standard approach to this issue in both political theory and intellectual history has been to derive accounts of anarchist political theory from the writings of a handful of 'canonical' figures, a habit which, as noted, is especially evident in postanarchist political theory. At the highest level of generality, postanarchism may be defined as a current in anarchist political theory that is informed by and critically engages with poststructuralist philosophy. Within this current, we can identify, following Benjamin Franks, at least three specific orientations:

First, a strident, Lyotardian Postanarchism, that rejects traditional anarchist concerns, and instead proposes the adoption of new critical approaches and tactics that lie beyond the remit of anarchist orthodoxy, using as their basis those poststructural theorists that are antipathetic to traditional anarchism. Second, a redemptive postanarchism that seeks the adoption into anarchism of poststructural theory to enrich and enliven exiting practices, one which sees 'anarchism' as it currently stands as lacking, but amenable to change. Third, and finally, a postmodern anarchism (which corresponds to the last version of post-Marxism), that reapplies anarchist analyses and methods to the new globalized, postPruitt-Igoe political economy, and concentrates on the actions of oppressed subjects. ${ }^{11}$

The second orientation, which is arguably the most prominent within the anarchist studies milieu, is chiefly associated with Newman and May. As Newman writes, for example, "[P]ostanarchism is not a transgression or a movement beyond the terms of anarchism... [rather] it seeks to destabilise the foundationalism on which the discourse of classical anarchism rests. Its deconstructive tools are poststructuralist thought and elements of psychoanalytic theory.”12 May adds: "Poststructuralist political theory replaces traditional anarchism's a priori with, on the one hand, the positivity or creativity of power and, on the other, the idea that practices or groups of practices (rather than subject or structure) are the proper units of analysis.”"13

Unlike other recent theoretical engagements with classical anarchism, ${ }^{14}$ postanarchism is a project that is self-consciously engaged with and responding to classical anarchism. As the 
above quotations from Newman and May make clear, however, postanarchists believe that classical anarchism has significant shortcomings (e.g., essentialistic accounts of human nature, naively progressive views of history, a tendency to valorize the natural sciences, and so on) which can be remedied through an engagement with poststructuralist and psychoanalytic theory. Yet, despite the iconoclastic urge that underpins their challenge to the historical tradition of anarchism, adding nuance to this history has never been the postanarchists' métier. Rather, mirroring the approach of mainstream political theory, postanarchists have been intent on fixing the contributions, and detailing the shortcomings, of classical anarchists, instead of examining the complexity of these ideas at the point of their articulation.

The failure of postanarchism to engage with the social and political history of the anarchist movement beyond the canon represents a deeper problem. Postanarchists have tended to derive their understanding of anarchist political theory almost entirely from the writings of canonical thinkers, allowing the latter to stand in as a monolithic expression or representation of the intellectual life of the classical anarchist movement. In so doing, postanarchism overlooks the depth and variety of anarchism's intellectual history. As we noted above, however, even postanarchism's reading of the canon is fraught, having been accused of oversimplifying or otherwise misrepresenting the ideas expressed in 'canonical' anarchist works (a significant accusation by itself, since the postanarchist project relies so heavily on identifying what it takes to be the shortcomings of classical anarchism). But how exactly does postanarchism gets these thinkers wrong? Much has already been said about what might be called "intratextual” problems of methodology — that is to say, problems with how parts of texts are interpreted in relation to the whole, or in relation to other writings by the same author. (Examples would include overly narrow or selective reading, the construction of strawman arguments, and so on.) Comparatively 
less attention has been paid to the various ways in which postanarchist writers misunderstand or ignore the broader context within which classical anarchist ideas developed—for example, by failing to take into account their relationship to contemporaneous intellectual, political, and social controversies in the late nineteenth and early twentieth centuries. It is this problem that we discuss in this essay.

To be clear, we are not claiming that the general motives of the postanarchists are misguided. It is surely worthwhile to explore critically the strengths and limitations of classical anarchist political theory, especially within the context of recent and contemporary Continental thought. Doing so honestly and fruitfully, however, requires a more nuanced understanding of classical anarchist political theory, which in turn requires a sufficiently contextual approach to reading and interpreting anarchist texts. In the next section, we demonstrate how such an approach might work using selected writings from Kropotkin; who, as one of the most commonly discussed anarchist thinkers, and a key target of postanarchist critique, is a potent example when considering the shortcomings of recent theoretical appreciations of his work. Our hope going forward is that future political-theoretical discussions of anarchism will take inspiration from this example, and pursue more rigorous examinations of anarchist history.

\section{On Kropotkin: Science and the Substance of History}

Like every political ideology, the ideas that have historically comprised anarchism are the product of debate and contestation. And, for any political doctrine to endure, these core ideas must necessarily possess enough flexibility for reapplication as tools of critique outside of the context of their immediate articulation. The contemporary resurgence of interest in anarchism demonstrates that, as with the ideologies that dominate political discourse, anarchist theory 
displays an attendant level of intellectual pliability, inspiring critics and activists beyond the site of its historical development as a tradition in the nineteenth century. As much as political theorists look to the past, then, they also have an inbuilt desire to overcome their progenitors, and in this anarchism is a more Oedipal tradition than most. For postanarchists, surveying the field of anarchist history is both a source of inspiration and embarrassment. The pursuit of meaningful social freedom, secured through the overcoming of 'hierarchical social relations,' was the noble objective of anarchism's foundational thinkers, but their projects of emancipation were weighed down by the historical baggage of their intellectual context. ${ }^{15}$ Forged in the afterglow of the European Enlightenment, the instinct for human liberation ran through the core of anarchism, but it also manifested its imperfections: an essentialised vision of humanity; a progressive theory of history; and an eschatological faith that the antagonisms of the present would find resolution.

For a number of reasons, Peter Kropotkin is frequently pinpointed as the exemplar of this mentality. While praising Kropotkin for his forceful articulation of federalism, or trenchant defence of voluntarism, post-anarchists insist that the wider assumptions of his social philosophy blunt the radical edge of this politics. ${ }^{16}$ Central to this objection is the argument that Kropotkin placed undue faith in the interpretative and emancipatory potential of the scientific method, an attachment leading him to make dubious translations from the natural to social sciences following in the footsteps of oppressively rationalistic thinkers like Auguste Comte. Snared by these intellectual debts and the historical context that legitimised them, Kropotkin is charged with committing a number of allied crimes. He based his analysis of humankind on a dubious 'conception of universal animal nature', in turn positing the existence of an 'essentially benign' human nature that entailed an anodyne vision of a future free of coercion. ${ }^{17}$ This conception of humanity's innate goodness, one perverted by the morality fostered by class society, also 
engendered a faith in anarchism's ultimate triumph. Prone to borrowing the language of scientific 'laws', Kropotkin advanced a theory of historical development that discerned an 'inexorable' trajectory towards 'emancipation'. ${ }^{18}$ In short, Kropotkin's scientism is an embarrassing impediment:

It is understandable that Kropotkin would wish to deploy the semiotics of modern science against capital and the state, for in his time, scientific analysis appeared to be capable of addressing any and all problems. But Kropotkin's era was...followed by a century of instrumental reason run rampant, and it is for this reason that postmodernists such as Jean Baudrillard have argued that a rational, scientific language cannot possibly be used to articulate a truly radical politics. ${ }^{19}$

Modernity, as Zygmunt Bauman noted, 'is an age of artificial order and of grand societal designs, the era of planners, visionaries, and-more generally-'gardeners' who treat society as a virgin plot of land'. ${ }^{20}$ The politics of scientific rationalism led not to the fruit-tree lined streets of Henry George's vision, or the ventilated mine shafts of Kropotkin's imaginings, but to ossuaries and crematoria. ${ }^{21}$

The critique of Kropotkin's work is therefore foundational to the postanarchist political identity, and his ambitions of rooting anarchist politics in the discourses of nineteenth century science an obvious foil for attempts of contemporary theorists to break out of the confines of a seemingly antiquated politics. Postanarchists have thus launched a robust critique of the historical anarchist tradition, which has posed many searching questions, but their evaluation has itself met stubborn opposition. It is worth noting, for instance that, post-structuralist patina aside, scepticism regarding the emancipatory potential and internal coherence of Kropotkin's philosophy is not uncommon. Liberal political theorists like David Miller, and the historian of anarchism George Woodcock, both noted the conflict between Kropotkin's apparent historicism and his commitment to revolution. ${ }^{22}$ Indeed Malatesta, the Italian anarchist who shared 
Kropotkin's exile in London, opposed his friend's commitment to unveiling anarchism's scientific basis. Rejecting the utility of the 'mechanical concept', he warned of the fatalistic implications for anarchist praxis: 'everything is determined, inevitable, nothing can be other than what it is' ${ }^{23}$

For the historian of political thought, it is also not necessarily post-structuralism to which they would turn for a critique of the potentially illiberal implications of political utopianism, but the dissection of the totalitarian temper advanced by thinkers like Isaiah Berlin, Karl Popper, and Leszek Kołakowski decades earlier. ${ }^{24}$ And more significantly, from Kropotkin to Marie-Louise Berneri and beyond, there is a rich history within the anarchist tradition of challenging the authoritarianism lurking in the shadows of the cities sketched by utopian dreamers. ${ }^{25}$ Even Kropotkin, the alleged doyen of mechanistic social science, winced at the lack of flexibility in Icarian colonies and Fourierian phalanesteries, dismissing their unduly optimistic vision of a communal life purged of conflict. ${ }^{26}$ As he insisted, offering a preface to Emile Pataud and Emile Pouget's syndicalist utopia How We Shall Bring About the Revolution (1913), the future remained not only unwritten, but unwritable: 'life is infinitely more complicated than anything that can be foreseen'. ${ }^{27}$

The failure of postanarchists to appreciate the complexity of Kropotkin's thought stems partly from a broader lack of sensitivity to the history of anarchism, both as an historically constituted intellectual tradition and as a social movement. Kropotkin's relationship to Charles Darwin is one example in which this absence of historical acuity is particularly apparent. Given that Darwin cast a long shadow over nineteenth-century letters, one that traversed disciplinary boundaries in being equally important to social thought, it is unsurprising that Kropotkin, interested in both natural and social philosophy, should respond to his ideas. While postanarchist 
commentators tend to overlook the fact that Kropotkin was not offering a riposte to Darwin in Mutual Aid (1902) but protecting Darwinian theory from its perversion as a justification of narrow individualism, his deeper reading of evolutionary theory problematises the view of his narrow essentialism. ${ }^{28}$ As Newman and May argue, Kropotkin's 'theory of social relations' rested on the idea of 'an innate tendency towards mutual aid and assistance, something we have inherited from the animal world', and therefore that 'human beings have a nature or essence; and...that that essence is good or benign' ${ }^{29}$

While this interpretation of Kropotkin's Darwinism informs the charge that he held a naively progressive view of history, with the inevitable triumph of the tendency to sociality, in reality his evolutionary theory is more complex. Beyond the pages of Mutual Aid, Kropotkin wrote frequently about the importance of Darwin's work, placing it at the apex of nineteenthcentury scientific achievement. ${ }^{30}$ Central to his perception of On the Origin of Species (1859) significance, however, was not that it pointed to the importance of cooperation in animal societies, but that it finally destroyed the idea of species’ immutability. Buffon, Linnaeus, and Lamarck had all pointed in this direction, but Darwin decisively revealed 'the idea of...continuous development (evolution) and of a continual adaptation to changing environment'. ${ }^{31}$ While criticised for adopting a teleological view of history, Kropotkin cleaved to a Darwinian explanation of evolution that had itself been inspired by a rejection of the teleology of Jean-Baptiste Lamarck, who looked to the direct adaptation of organisms to their environment as the motor of evolutionary change. As Darwin objected, this commitment to perfectibility struggled to explain the endurance of the 'lowest forms' of life:

Lamarck, who believed in an innate and inevitable tendency towards perfection in all organic beings, seems to have felt this difficulty so strongly he was led to support that new and simple forms are continually...produced by spontaneous generation. 
As Darwin countered, this was not a problem for 'our theory' of natural selection, as 'natural selection...does not necessarily include progressive development—it only takes advantage of such variations as arise and are beneficial to each creature under its complex relations of life' ${ }^{32}$ Despite the confidence of his claim, before the rediscovery of Mendelian genetic theory in the early twentieth century, the line between Lamarckian and Darwinian explanations of evolution was a fine one. The debates between the proponents of either approach tended to generate more heat than light, and the divide between them was porous, with Darwin himself making concessions to direct adaptation. Following the completion of Mutual Aid, Kropotkin threw his energy into these technical discussions, emphasising Darwin's latent Lamarckism, and thus the dual importance of direct adaptation and natural selection.

Although Kropotkin's interpretation of evolutionary inheritance is now outmoded, the important point to gather from his work, which included a polemical dissection of the archDarwinian August Weismann, was his stress on constant modification as the principle of organic life. In 1912, for instance, Kropotkin published an essay summarising recent scientific researches, and concluded that the 'hereditary transmission of acquired characters' was increasingly being shown to be an axiom of organic evolution. ${ }^{33}$ Two-years later, as Kropotkin was losing face for supporting the Allies in the First World War, he published a further examination of inheritance in plants that reiterated the rapidity of change:

Varied experiments [have shown] that changes which we formerly believed would require scores of years to be produced by a natural selection of accidental variations are obtained in the experimental field or the laboratory in the lifetime of the individual by a mere change of environment. ${ }^{34}$

Indeed, so important was mutability that Kropotkin concluded that it was fundamental to evolutionary survival: 
Variability, which Darwin described as a 'handmaid to Natural Selection,' offers to her lady such a profusion of variations that the lady's preferences are determined beforehand. All that she has to do is to weed out those, probably sickly, individuals which are not plastic enough and do not answer rapidly enough the requirements of a changed environment by corresponding structural changes. ${ }^{35}$

When writing to the botanist Joseph Hooker in 1844, long before he made his theory of evolution public, Darwin confided, with characteristic circumspection, that ' $\mathrm{I}$ am almost convinced...that species are not...immutable...[and] I think I have found out...the simple way by which species become exquisitely adapted to various ends'. In the intellectual climate of the time, he added, this was 'like confessing to a murder' ${ }^{36}$ Kropotkin noted this observation with approval, as further evidence of Darwin's revolutionary genius, as he demonstrated that 'there are no immutable species: that all of them give birth to countless variations'. ${ }^{37}$

As postanarchists rightly suggest, Kropotkin drank deeply from the well of nineteenth century science, but their efforts to understand this debt have been impoverished by an absence of contextualisation. Lacking an appreciation of the wider intellectual context that informed the borrowing of concepts from the natural sciences in the late-Victorian period, they fail to appreciate the complexities and uniqueness of his thought. As towards the end of the century biology displaced physics as the science achieving the most profound discoveries, social theorists increasingly reached for organic analogies to buttress their interpretations of society. ${ }^{38}$ Kropotkin followed suit, but for all the connections made between his scientism, essentialised view of humanity, and Panglossian confidence in the course of social development, the translation of evolutionary theory was heterogeneous, and rarely informed a simple narrative of steady progress. Even a thinker like Herbert Spencer, who enshrined evolutionary development at the heart of his grand intellectual system, insisted on the possibility of regression: 
The cosmic process brings about retrogression as well as progression, where the conditions favour it. Only amid an infinity of modifications, adjusted to an infinity of changes of circumstances, do there now and then occur some which constitute an advance...Evolution does not imply a latent tendency to improve, everywhere in operation. There is no uniform ascent from lower to higher...only an occasional production of a form which, in virtue of greater fitness for more complex conditions, becomes capable of a longer life... What thus holds with organic types must hold also with types of societies. ${ }^{39}$

Revealingly, Kropotkin was deeply indebted to Spencer's work on evolutionary theory. But as much as Spencer recognised a potential for decline, for other thinkers the organicist model had implications that were more dramatic. The perceived morbidity of fin de siècle European thought derived in part from a sense that evolutionary theory could entail the opposite of progressive development, and to speak of society and history in organic terms opened the door to notions of decline, stagnation, and death. That this pervasive fear of 'degeneration’ had sinister implications is well known. ${ }^{40}$ For a scientist like Karl Pearson, holder of the quickly renamed Galton Chair of Eugenics at University College London, ‘the doctrine of evolution' unequivocally applied 'to the history of nations'. The 'continual progress of mankind', he wrote in 1900, 'is the scarcely recognized outcome of the bitter struggle of race with race, like all other life, being subject to the stern law of the survival of the fitter'. The 'hecatombs of inferior races' pave the 'path of progress', he added, and to flinch before this natural law would be a mistake, only leading the 'superior race...[to] degenerate itself'. ${ }^{41}$

Pearson's comments reflected a broader sense of anxiety in certain European intellectual circles concerning, to borrow a phrase from a figure equally interested in eugenic ideas, the shape of things to come. Indeed, H.G. Wells' depiction of the cannibalistic Morlocks preying on the effete Eloi in his The Time Machine was something of a warning, freighted as it was with the terminology of decline: 
The too-perfect security of the Upper-worlders had led them to a slow movement of degeneration, to a general dwindling in size, strength, and intelligence...What had happened to the Under-grounders I did not yet suspect; but from what I had seen of the Morlocks....I could imagine that the modification of the human type was even more profound than among the 'Eloi'. ${ }^{42}$

The power of Wells' novella, first published in 1895, stemmed from the purchase that these fears possessed. In 1894, for instance, another Cassandra of stagnation Benjamin Kidd had published his highly influential Social Evolution, and like Pearson's intervention, pointed to competition as the engine of national progress:

It is now coming to be recognized as a necessarily inherent part of the doctrine of evolution, that if the continual selection which is always going on amongst the higher forms of life were to be suspended, these forms would not only possess no tendency to make progress forwards, but must actually go backwards...That is to say...a process of slow but steady degeneration would ensure. ${ }^{43}$

What is perhaps most surprising for modern readers is that Pearson, Wells, and Kidd were all men of the left. Pearson identified as a socialist, albeit of a 'regimented' kind, championing modern socialism’s efforts in helping to 'leaven’ progressive legislation, and argued that 'society ought to be one vast guild of laborers... and so organized there would be no place...for those who merely live on the work of others'. ${ }^{44}$ While obstinately refusing to join any group, Pearson kept abreast of events in London's late-Victorian radical scene, and corresponded regularly with Charlotte Wilson, later a founder alongside Kropotkin, and first editor of, Freedom newspaper. ${ }^{45}$ Kidd's belief in the vivifying qualities of competition, on the other hand, might seem characteristic of an aggressive form of individualistic liberalism, but he also looked to a state led 'social enfranchisement' building on the successes of political enfranchisement. Securing 'equal social opportunities' through state action was therefore central to his schema, meaning that he lay close to Fabianism — the influential socialist group founded in 1884 that looked to the gradual realisation of socialism through existing political agencies. ${ }^{46}$ The politically unorthodox Wells 
lay even closer to the Fabians, joining them in 1903, although his membership only lasted last four years. ${ }^{47}$ Calling for a greater professionalisation of the Society, Wells looked beyond the Fabians' paternalistic 'Toryism' to a technocratic elite that would shape social life. ${ }^{48}$ A 'New Republic' of 'intelligently critical men [sic]' would replace the 'great swollen, shapeless, hypertrophied social mass of to-day’. ${ }^{49}$

All this may seem to cast little light on Kropotkin's social thought, but in fact an appreciation of this intellectual context allows the modern reader to see the idiosyncrasies of his position, and the contextual commonalities, more clearly. All of these thinkers - Pearson, Wells, Kidd, and Kropotkin - shared a sense that degeneration and decline were discernible aspects of social development. Kropotkin differed in seeing the best way to address this in the expansion of mutual aid, rather than the institution of stern authority, but its real significance rests in what it demonstrates about his overarching vision of history and its commitment to a sense of decline, an appreciation which is wholly absent in postanarchist readings of his work. Given Pearson and Kidd's renown, Kropotkin would certainly have been familiar with their understanding of retrogressive evolution. Pearson actually received a mention in one of Kropotkin's follow-up articles to Mutual Aid, in which he praised his work in the statistical analysis of variability'biometry' — and suggested that this new field of biology was inclining to confirm the limited evolutionary role of chance variation. ${ }^{50}$ He may have been unaware of Wells' work, but Wells' fame as a popular fiction writer and essayist further attests to the prominence of these tropes of degeneration in British intellectual life in this period. Moreover, Kropotkin was evidently anxious about where some of this rhetoric was tending. The First International Eugenics Congress held in London in July 1912 attracted delegates from around the world, and Kropotkin contributed a speech entitled 'The Sterilization of the Unfit', later published in both Freedom 
and Emma Goldman's Mother Earth. Praising the Italian economist Achille Loria who in a previous discussion had condemned the inherent elitism at work in the sterilisation debate, Kropotkin argued, in line with his broader theoretical work on evolution, that the proponents of restrictive measures were failing to appreciate 'the influence of surroundings upon the soundness of what is transmitted by heredity'. ${ }^{51}$ Social renewal offered a better hope of improving 'the germ plasm' than 'any amount of sterilization', he added, suggesting that to 'destroy the slums' was a necessary first step. Nevertheless, despite being unpersuaded by the scientific value of eugenic theory, it is apparent that Kropotkin readily bought into the potential of social degeneration:

The great question which we all have at heart [is] the prevention of the deterioration and the improvement of the human race by maintaining in purity the common stock of inheritance of mankind. ${ }^{52}$

Not sterilisation but socialism was Kropotkin's solution to this problem, and he chided enthusiasts of eugenics for failing to recognise the social roots of the issues they raised: illness, crime, and errant sexual behavior.

If Kropotkin's evolutionary theory placed mutability at its heart, and he believed in the possibility of retrogression, it follows that the notion that he trusted in the ineluctable triumph of anarchism must be qualified. His understanding of this historical process, propounded notably in Mutual Aid and The State: Its Historic Role (1896) certainly does not support such a reading. Rather than steady progress, Kropotkin saw in history a simplistic clash of eternally antagonistic forces: a tendency to social cooperation and mutual aid, and a competing impulse to domination and egotism. The State closed by enshrining this narrative in a choice:

Yes: death - or renewal! Either the State for ever, crushing individual and local life, taking over in all fields of human activity, bringing with it its wars and its domestic power struggles, its palace revolutions which replace...one tyrant by another, and 
inevitably at the end of this development there is...death! Or the destruction of the State, and new life starting again in thousands of centers on principle of the lively initiative of the individual and groups and that of free agreement. The choice lies with you! ${ }^{53}$

Kropotkin's broader historical narrative stressed that often in history people had not opted for the 'choice' of free agreement. The Roman state, for him the epitome of centralised control, grew to co-opt and supplant the communal institutions created in the 'societies, bands, or tribes' that had made life possible for early humans. ${ }^{54}$ In turn, reflecting the penchant for medieval craft labor amongst early socialists, Kropotkin saw in the European communal movement a bold affirmation of individual liberty against the pretty-despotisms of the Dark Age. ${ }^{55}$ So too, in the streets of the city-states, he discerned cooperative institutions that provided a base for energetic intellectual enquiry, enabling scientific discoveries and artistic achievements. But these liberties were also precarious, and from the sixteenth century he saw the modern state exploiting internal weaknesses to rise from the rubble of these walled cities. ${ }^{56}$ More than ever before, the state absorbed 'all social functions,' and nurtured a 'narrow-minded individualism' as obligations to the state replaced the bonds of fellowship. ${ }^{57}$ Yet, ever the optimist, Kropotkin believed that this spirit of mutual aid had not been obliterated, and as much as this Goliath trampled social solidarity, shoots of resistance sprouted between its toes.

While unsophisticated, Kropotkin's historical narrative, built as it is upon his reading of evolutionary theory, eschews any simple idea of steady progress. In arriving at this theory of historical development he was, as with every thinker, engaged in a conversation with the concerns and current fashions characterising the contemporary intellectual climate. These debts and dialogues are vital in fathoming the distinct contribution a thinker like Kropotkin was hoping to make to the history of anarchist ideas, and the act of contextulisation adds nuance to theories 
and concepts that have tended to become streamlined as they promenaded across the page in general textbooks of political thought from the mid-twentieth century. This much is clear in appreciating the multifaceted debates concerning evolutionary theory, and Kropotkin's efforts to reach his own comprehension of evolution in contrast - but also in certain respects in accordance with - other scholars grappling with the issue. Such a focus uncovers both the simplicity of appreciations of his position on evolution, which is not unique to postanarchist critics, and the utility of the historical gaze in comprehending past ideas. The notion of decline at the heart of Kropotkin's historical theory further demonstrates that while he is assailed for offering a narrowly progressive and teleological interpretation of the historical record, the reality is more complex. Contextualising his evolutionary theory betrays the particularity of the postanarchist reading of his work in this regard, and looking to the actual practice of history, as it developed as self-conscious discipline in the nineteenth century, further reveals the tendency to paint an unsophisticated picture of the period's intellectual history.

Kropotkin's turn to historical narrative as an explanatory device - and an historical sense pervaded his entire philosophy - was itself a vital comment on the importance of history in his late-Victorian context. The Whig historians that had turned to historical investigation to trace the path of English exceptionalism certainly thought so, and the fact that Sir Edward Creasy's A Text-Book of the Constitution (1848) went through sixteen print-runs in the nineteenth century, and that the first volumes of Thomas Babington Macauley's History of England (1848) were instant bestsellers, suggests that this was an idea with a popular purchase. ${ }^{58}$ But while the 'Victorians plundered the past for the raw stuff of imagination' and history became the 'mainstay of meaningfulness' in an increasingly secular intellectual climate, Kropotkin’s take on history abjured the celebration of the modern nation-state that was a prime concern of these historians. ${ }^{59}$ 
Indeed, the selective vision of the discipline of history was a regular recipient of his ire. Noting this Victorian tendency to celebrate the state, Kropotkin wrote that a change was underway whereby history, 'after having been the history of kingdoms tends to become the history of nations and then the study of individuals', which he interpreted as an interest in the 'the members' of a nation, rather than a Carlylean celebration of genius. ${ }^{60}$ Elsewhere, he reflected on the difficulty for even the 'best-intentioned' historian to provide a real picture of the past, given institutional impediments and archival biases:

In our own time, the cumbersome records which we prepare for the future historian, in our Press, our laws courts, our Government offices, and even in our fiction and poetry, suffer from...one-sidedness. They hand down to posterity the most minute descriptions of every war, every battle....and act of violence...Ere long history will have to be re-written. ${ }^{61}$

To his mind, a different, more complex, history was needed. This history would not fixate on the modern state or humanity's sanguinary history, but look instead to understand the creative genius of historical communities that had struggled to survive against the odds, and the extra-state institutions they had established to make life livable.

History’s disciplinary history therefore forms an important context in understanding Kropotkin's interest in the past in the first place, and shows why he felt a pressing need to counter the fetish of the state beyond the boundaries of the narrowly political. Yet history's history in Britain shaped Kropotkin's efforts in other ways too. While Napoleon's defeat 'proved the perfection of the British constitution' to the Whiggish onlooker, the country's faltering imperial project at the end of the century, against a backdrop of ratcheting imperial competition and national humiliations like the 'Second Anglo-Afghan War, the Zulu Wars, the conflict with the Mahdi, [and] the Boer War', meant that history became instructive in a different way. ${ }^{62}$ Amidst anxieties about British imperial decline and the 
broader fear of degeneration considered above, historians became fascinated with the history of collapsing Empires. The 'specter of decline' that haunted Edward Gibbon's opus History of the Decline and Fall of the Roman Empire (1776), influenced a number of popular nineteenth-century historians, including John Robert Seeley, Thomas Dyer, Thomas Keightley, and Theodore Mommsen. All were preoccupied with the fraying threads of classical power, identifying a range of causes as responsible, from militarist usurpation of liberty, to endemic venality, to a loss of civic virtue. ${ }^{63}$ Kropotkin diverged in seeing this collapse as no bad thing, but the point is that his own historical narrative adopted a similar logic. His vision of history was not Gibbonian in the sense that Kropotkin saw history as a struggle between contending forces as opposed to a cyclical process, but overriding these differences was a fascination in the course and manifestation of societies' rise, decline, and disintegration. As much as the histories of Dyer or Keightley occasioned soul-searching in the corridors of the Colonial Office that Kropotkin would not have shared, his attempt to grasp the way in which history unfolded bore the imprint of these contemporary foci, refracted though a different lens. The promise of anarchism was meaningful freedom, but the lesson of history, shown in the demise of the village community and medieval commune, was that relative liberties were always vulnerable, and imperiled by inactivity.

Placing Kropotkin's theory of evolution in historical context reveals the risks involved when painting nineteenth century intellectual history with a broad brush. Indeed, in the postanarchist critique it often seems that there is a too-ready tendency to perceive this history in categorical terms: the eighteenth-century Enlightenment superseded by nineteenth century positivism, followed by twentieth-century critical theory and then post-structuralist iconoclasm. 
The reality is, of course, as useful as these categories can be, they frequently fail to capture the complexity of historical actors' intellectual commitments. Jean-Jacques Rousseau, entombed in the Panthéon in recognition of his influence on France's experiment in constructing a rational political culture was also one of the Enlightenment's first critics, and Sigmund Freud, the grand diagnostician of the irrational impulses lurking behind the veil, remained an apostle of the scientific method. ${ }^{64}$ Kropotkin's thought is similarly replete with these subtleties and antagonisms, and to appreciate it in anything but caricature, sensitivity to the context of its articulation is vital. Comte, Spencer, and Darwin were all fundamental influences on his thought, and he persistently discussed his politics in the language of contemporary science, but it is insufficient to see Kropotkin solely in terms of the 'cult of positivism.' While those reacting to this 'travestied' manifestation of Enlightenment values at the start of the twentieth century were condemning the mechanistic thinking of this tradition, Kropotkin was developing an ontology of continual change, perpetual antagonism, and temporary equilibrium. ${ }^{65}$ As Darwin and Lamarck had shown, as human history testified, and as modern physics was revealing, any 'adjustment will only last under one condition: that of being continually modified; of representing at every moment the resultant of all conflicting actions' ${ }^{66}$ Rather than an enervating determinism, it was this vision that Kropotkin hoped to enshrine in his politics.

\section{Conclusion: Political Theory and History}

It is easy to imagine the resigned sigh that might meet the call for theorists of anarchism to pay closer attention to the history of the movement and its ideas. Many would no doubt object to the Gradgrindian implications of this suggestion, and conjuring an image of the Victorian schoolmaster declaiming on the principal battles of the Peloponnesian War through a cloud of 
chalk dust, argue that the radicalism of any future political theory would be blunted by our sententious demand to learn the facts of history. Yet this would misunderstand both the ambitions of history as a discipline, and our object in insisting that this history is worth thinking about seriously.

As E.H. Carr noted long ago, when pondering that awkward question What is History? (1961), appeals to the sovereignty of facts is not enough. 'To praise a historian for his accuracy,' he wrote, 'is like praising an architect for using well seasoned timber...It is a necessary condition of his work, but not his essential function’ ${ }^{67}$ To mimic Proudhon or Foucault, a more accurate appraisal of the historian's role, therefore, is to question, uncover, complicate, challenge, nuance, clarify, explain, and connect. And for those interested in the history of ideas, their duty, as much as is possible, is to reveal past thought in all its detail and complexity; to uncover the reasons why diverse historical actors cleave to certain sets of ideas as useful tools of analysis for their present, and consider how these ideas emerge in response to the pressing questions of the day.

It follows then that any future political theory will necessarily be engaged in a conversation with the past, and for this theory to be a robust analysis of the present, it must appreciate the intricacies of this past. As the foregoing discussion of Kropotkin has suggested, perhaps viewing him as the purveyor of a mechanistic social science is not a sufficient appraisal of the ideas that defined his life. Sensitivity to the context that gave his ideas meaning in the first place shows that many nineteenth century assumptions and intellectual fashions shaped his thought, and understanding these allows a fuller appreciation of his political commitments. Further, it also stresses the notion that anarchism is a lived tradition that emerged through a constant process of reshaping and rethinking. This constant quest to articulate and rearticulate 
anarchism's claims not only involved anarchists debating amongst each other, but also demanded engaging with other traditions and other thinkers.

We have styled the foregoing analysis a 'prolegomena' because it is an invitation to further political-theoretical work that takes the intellectual history of anarchism seriously. This is, however, only a beginning. In order to achieve a wide enough scope, political theorists will also have to engage with its social and cultural history. Recent scholarship in anarchist historiography has broadened the horizons of this neglected past as never before, and provided us with a much fuller and richer understanding of the complex development of anarchism as a tradition of radical critique in the nineteenth century. ${ }^{68}$ Among other things, it has revealed the ways in which anarchist ideas emerged from, and were disseminated through, intricate transnational networks of communication, as well as via personal and organisational relationships. ${ }^{69}$ A diverse array of 'newspapers, books of poetry, theater scripts, art, and political polemics' percolated through these networks, carrying anarchist ideas across the globe, to be reimagined in fresh national contexts. ${ }^{70}$ As ideas were transmitted from one node to another, they were adapted and modified to meet the specific challenges facing activists and thinkers in these countries, and translated—both literally and figuratively—into prevailing cultural scripts. The ephemera of this movement, its books, but also its pamphlets, periodicals, and posters, leave echoes of this rich, fragmented, history.

To view anarchism, as many political theorists implicitly tend to do, as the invention of a select group of 'great men' is also reductive. Whatever the significance of Proudhon, Bakunin, and Kropotkin as the pioneers and tabulators of anarchist philosophy, the multifarious ways in which these ideas were rethought in diverse intellectual and cultural contexts, represents the lived history of this movement. The ink-smudged paper leaving the desks of a Kropotkin or 
Bakunin for the typesetter and printer was intended to inspire, invigorate, and inflame. This reemphasizes the fact that anarchism as a movement marshalled its intellectual and cultural production in the service of revolutionary transformation, and sensitivity to the reception of these ideas is therefore crucial.

We hasten to emphasise, however, that the study of 'canonical' thinkers should not be neglected as part of an overall strategy for understanding and appreciating classical anarchist ideas. Just as awareness of the reception of these ideas casts fresh light on their role in inspiring diverse actors, political theorists are obliged to treat the context of their articulation with greater care. For a self-consciously revolutionary tradition, it is axiomatic that anarchists did not simply talk amongst themselves, and just as anarchists tried to reach out to others, contemporary concerns made their imprint on anarchist theory. The foregoing discussion of Kropotkin's ideas points at just one instance where greater sensitivity to the broader context complicates prevailing assumptions about the nature of his intellectual contribution. This prolegomena is therefore also a call: for political theorists interested in anarchism to scrutinise the nuances and ambiguities of this past. Such a conversation will enliven both disciplines, while simultaneously recovering a neglected history from obscurity. Through the chalk dust, even this much is clear.

\footnotetext{
${ }^{1}$ See, for example, V.I. Lenin, Marxism versus Anarchism (Chippendale: Resistance Books, 2001): p. 18.

${ }^{2}$ See Nathan Jun, 'Anarchist Philosophy and Working Class Struggle,' WorkingUSA: The Journal of Labor and Society 12 (3) (2009): pp. 505-519.

${ }^{3}$ For a recent overview of this approach, see Matthew S. Adams, 'The Possibilities of Anarchist History: Rethinking the Canon and Writing History,' Anarchist Developments in Cultural Studies 1 (2013): pp. 34-63, pp. 34-38. For a classic discussion, see Quentin Skinner, 'Meaning and Understanding in the History of Ideas,' in J. Tully (Ed.) Meaning and Context: Quentin Skinner and His Critics, (Cambridge: Polity Press, 1988): pp. 29-67, p. 30.

${ }^{4}$ There are important exceptions to this tendency. Consider, for example: Ruth Kinna, 'Guy Aldred: Bridging the Gaps between Marxism and Anarchism', Journal of the Political Ideologies, 16 (1) (2011), pp.97-114; Ruth Kinna, 'Anarchism and the Politics of Utopia' in Laurence Davis and Kinna (Eds.) Anarchism and Utopianism (Manchester, Manchester University Press, 2009), pp.221-240; Ruth Kinna, 'Fields of Vision: Kropotkin and Revolutionary Change', SubStance, 36 (2) (2007), pp.67-86; Benjamin Franks, Rebel Alliances: The Means and Ends of Contemporary British Anarchisms (Edinburgh: AK Press, 2006); Carl Levy, 'Anarchism and
} 
Cosmopolitanism', Journal of Political Ideologies, 16 (3) (2011), pp.265-278; Carl Levy, 'The Rooted

Cosmopolitan: Errico Malatesta, Syndicalism, Transnationalism and the International Labour Movement' in David

Berry and Constance Bantman (Eds.) New Perspectives on Anarchism, Labour \& Syndicalism (Newcastle:

Cambridge Scholars, 2010), 61-79; David Berry, 'Metamorphosis: The Making of Daniel Guérin, 1904-1930',

Modern \& Contemporary France, 22 (3) (2014), pp.321-342.

${ }^{5}$ Adams, 'Possibilities of Anarchist History,' pp. 37, 38.

${ }^{6}$ Representative texts include Todd May, The Political Philosophy of Poststructuralist Anarchism (State College, PA: The Pennsylvania State University Press, 1994) and Saul Newman, The Politics of Postanarchism (Edinburgh: Edinburgh University Press, 2011).

${ }^{7}$ See, for example, Allan Antliff, 'Anarchy, Power, and Postructuralism,' SubStance 36 (2) (2007): pp. 56-66; Jesse Cohn, 'What is "Postanarchism” Post?,' Postmodern Culture 13 (1) (2002); Benjamin Franks, 'Postanarchism: A Critical Assessment,' Journal of Political Ideologies 12 (2) (2007): pp. 127-145; Nathan Jun, Anarchism and Political Modernity (New York: Continuum, 2012)

${ }^{8}$ The philosophical anarchism of Robert Paul Wolff, A.J. Simmons, and associated writers has been criticized along similar lines. Representative texts include: A.J. Simmons, Moral Principles and Political Obligations (Princeton, NJ: Princeton University Press, 1979); A.J. Simmons, 'Philosophical Anarchism' in For and Against the State, ed. J. Sanders and J. Narveson (Lanham, MD: Rowman and Littlefield, 1996), pp. 19-40; A.J. Simmons, 'The Anarchist Position: A Reply to Klosko and Senor,' Philosophy and Public Affairs 16:3 (1987), pp. 269-279; and Robert Paul Wolff, In Defense of Anarchism (New York: Harper and Row, 1970).

${ }^{9}$ On the influence of postanarchism in political theory, see Franks, 'Postanarchisms: A Critical Assessment,' p. 127. ${ }^{10}$ Michael Freeden, Ideologies and Political Theory: A Conceptual Approach (Oxford: Oxford University Press, 1996): p. 1.

${ }^{11}$ Franks, 'Postanarchisms'., p. 130.

${ }^{12}$ Newman, The Politics of Postanarchism, p. 5.

${ }^{13}$ May, Postructuralist Anarchism, p. 87.

${ }^{14}$ See note 7 above. For a critique of philosophical anarchism, see Benjamin Franks, 'Anarchism and Analytical Philosophy,' in The Continuum Companion to Anarchism(Ed.) Ruth Kinna (New York: Continuum, 2012): pp. 5374.

${ }^{15}$ Lewis Call, Postmodern Anarchism (Lanham, MD: Lexington Books, 2002): p. 14.

${ }^{16}$ Call, Postmodern Anarchism, p. 14; May, Poststructuralist Anarchism, p. 57.

${ }^{17}$ Andrew M. Koch 'Post-Structuralism and the Epistemological Basis of Anarchism' in Post-Anarchism: A Reader, eds. Duane Rousselle and Sureyyya Evren (London: Pluto, 2012): pp. 23-40, p. 25; Saul Newman, 'Post-Anarchism and Radical Politics Today' in Post-Anarchism: A Reader, pp. 46-69, p.61.

${ }^{18}$ Newman, Politics of Postanarchism, p. 61.

${ }^{19}$ Call, Postmodern Anarchism, pp. 16-17.

${ }^{20}$ Zygmunt Bauman, Modernity and the Holocaust (Ithaca: Cornell University Press, 1989): p. 113.

${ }^{21}$ Henry George, Progress \& Poverty: an Inquiry into the Cause of Industrial Depressions (London: William Reeves, 1884), p. 353; P. Kropotkin, The Conquest of Bread (London: G.P. Putnam, 1907), p. 146.

${ }_{22}$ David Miller, Anarchism (London: J.M. Dent, 1984), pp. 62-77; George Woodcock and Ivan Avakumović, The Anarchist Prince: A Biographical Study of Peter Kropotkin (New York: Schocken, 1971), pp. 243-6.

${ }^{23}$ Errico Malateta, Errico Malatesta: His Life \& Ideas(Ed.) Vernon Richards (London: Freedom, 1965), pp. 43-44.

${ }^{24}$ Leszek Kołakowski, Modernity on Endless Trial (Chicago: University of Chicago Press, 1990), p.142; Isaiah Berlin, Liberty (London: Oxford University Press, 2002), p.112; Isaiah Berlin, 'The Decline of Utopian Ideas in the West', in Henry Hardy (Ed.) The Crooked Timber of Humanity: Chapters in the History of Ideas (Princeton, NJ: Princeton University Press, 1998), pp.20-48; Karl Popper, The Open Society and Its Enemies: Volume 1: The Spell of Plato (London: Routledge,1945); Karl Popper, The Logic of Scientific Discovery (London: Harper, 1965), p.41. See also: Matthew S. Adams, Kropotkin, Read and the Intellectual History of British Anarchism: Between Reason and Romanticism (Basingstoke: Palgrave, 2015).

${ }^{25}$ See: Kinna, 'Anarchism and the Politics of Utopia', pp. 221-240; Marie Louise Berneri, Journey through Utopia (London: Routledge, 1950).

${ }^{26}$ Matthew S. Adams, 'Rejecting the American Model: Peter Kropotkin's Radical Communalism' in History of Political Thought 35 (1) (2014), pp. 147-173. 
${ }^{27}$ Peter Kropotkin, 'Preface' to Emile Pataud and Emile Pouget, How We Shall Bring About the Revolution: Syndicalism and the Co-operative Commonwealth (London: Pluto Press, [1909] 1990), p. xxxiii.

${ }^{28}$ Koch, 'Post-structuralism,' p. 25; May, Poststructuralist Anarchism, p. 62.

${ }^{29}$ Saul Newman, 'Postanarchism: a politics of anti-politics,' Journal of Political Ideologies, 16 (3) (2011), pp. 313327. See also May, Poststructuralist Anarchism, p. 63.

${ }^{30}$ Peter Kropotkin, Modern Science and Anarchism (New York: Mother Earth Publishing, 1908), p. 34.

${ }^{31}$ Kropotkin, ibid., p. 36.

${ }^{32}$ Charles Darwin, The Origin of Species (New York: P.F. Collier, 1909), p. 136.

${ }^{33}$ P. Kropotkin, 'Inheritance of Acquired Characters,' The Nineteenth Century (March 1912), pp. 511-531, p.531.

${ }^{34}$ P. Kropotkin, 'Inherited Variation in Plants,' The Nineteenth Century (October 1914), pp. 816-836, p.816.

${ }^{35}$ Kropotkin, Ibid., p. 833.

${ }^{36}$ Charles Darwin, More Letters of Charles Darwin: A Record of His Work in a Series of Hitherto Unpublished Letters(Ed.) Francis Darwin (London: John Murray, 1903), pp. 40-41.

${ }^{37}$ P. Kropotkin, 'The Theory of Evolution and Mutual Aid,' The Nineteenth Century (January 1910), pp. 86-107, p. 88.

38 This was, however, a complex relationship. See: H.S. Jones, Victoria Political Thought (Basingstoke: Palgrave, 2000), pp. 74-81.

${ }^{39}$ Herbert Spencer, The Principles of Sociology: Volume III (New York: D. Appleton, 1900), pp. 609-10.

40 J.W. Burrow, The Crisis of Reason: European Thought, 1848-1914 (New Haven: Yale University Press, 2000), pp. 96-104.

${ }^{41}$ Karl Pearson, National Life from the Standpoint of Science: An Address Delivered at Newcastle (London: Adam and Charles Black, 1901), pp. 60, 61-2, 44.

${ }^{42}$ H.G. Wells, The Time Machine: An Invention (New York: Henry Holt, 1922), p. 118.

${ }^{43}$ Italics are Kidd's own. Benjamin Kidd, Social Evolution (London: Macmillan, 1894), pp. 36-7.

${ }^{44}$ Michael Freeden, 'Eugenics and Progressive Thought: A Study in Ideological Affinity,' The Historical Journal, 22 (3) (1979), pp. 645-671; Karl Pearson, The Ethic of Freethought and Other Addresses and Essays (London: Adam and Charles Black, 1901), pp. 301, 338.

${ }^{45}$ Theodore M. Porter, Karl Pearson: the Scientific Life in a Statistical Age (Princeton, NJ: Princeton University Press, 2004), pp. 108-110.

${ }^{46}$ Kidd, Social Evolution, p. 229; Jones, Victorian Political Thought, p. 85.

${ }^{47}$ Edward R. Pease, The History of the Fabian Society (London: Frank Cass, [1918] 1963), p. 163.

${ }^{48}$ Rodney Barker, Political Ideas in Modern Britain: In and After the Twentieth Century (London: Routledge,1997), p. 51.

${ }^{49}$ H.G. Wells, Anticipations: of the Reaction of Mechanical and Scientific Progress Upon Human Life and Thought (London: Chapman \& Hall, 1902), pp. 262, 271.

${ }^{50}$ Kropotkin, 'Theory of Evolution and Mutual Aid,' p. 105.

${ }^{51}$ P. Kropotkin, 'The Sterilisation of the Unfit,' Freedom: A Journal of Anarchist Communism (October 1912), pp. 77-78: 77; Maria Sophia Quine, 'Eugenic Revolution in Southern Europe: Science Sans Frontières', in Alison Bashford et al (Ed.) in The Oxford Handbook of the History of Eugenics (London: Oxford University Press, 2010), pp. 377-397, p. 380.

${ }^{52}$ Kropotkin, 'Sterilisation of the Unfit,' p. 78.

53 Peter Kropotkin, 'The State: Its Historic Role [1896]', in George Woodcock (Ed.) Fugitive Writings (Black Rose Books: Montréal, 1993), pp. 159-201: 201.

${ }^{54}$ P. Kropotkin, Mutual Aid: A Factor of Evolution (London: William Heinemann, 1902), p. 79.

${ }^{55}$ Kropotkin, Ibid., p. 162.

${ }^{56}$ Kropotkin, Ibid., pp. 215, 217.

${ }^{57}$ Kropotkin, Ibid., p. 227.

58 Jones, Victorian Political Thought, 54.

${ }^{59}$ Rosemary Jann, The Art and Science of Victorian History (Columbus, Ohio State University Press, 1985), pp. xi, 207.

${ }^{60}$ Peter Kropotkin, Anarchism: Its Philosophy and Ideal (London: Freedom, 1897), 7.

${ }^{61}$ Kropotkin, Mutual Aid, pp.116-117. 
${ }^{62}$ Michael Bentley, 'Shape and Pattern in British Historical Writing, 1815-1945', in Stuart Macintyre et al (Eds.) The Oxford History of Historical Writing: Volume 4: 1800-1945 (Oxford: Oxford University Press, 2011), 204-224 (207); C.A. Hagerman, Britain's Imperial Muse: The Classics Imperialism, and the Indian Empire, 1784-1914 (Basingstoke: Palgrave, 2013), p.119

${ }^{63}$ Hagerman, Britain's Imperial Muse, p. 49.

${ }^{64}$ Graeme Garrard, Rousseau's Counter-Enlightenment: A Republican Critique of the Philosophes (Albany, NY: SUNY, 2003).

${ }^{65}$ H. Stuart Hughes, Consciousness and Society (New Brunswick, NJ: Transaction, [1958] 2004), p. 29.

${ }^{66}$ Kropotkin, Anarchism: Its Philosophy and Ideal, 6.

${ }^{67}$ E.H. Carr, What Is History? (London: Macmillan, 1961), p. 5.

${ }^{68}$ For a detailed overview of this literature, see C. Levy, 'Social Histories of Anarchism,' Journal for the Study of Radicalism 4:2 (2010), pp. 1-44.

69 See, for example, Bert Altena and Constance Bantman, eds., Scales of Analysis in Anarchist Studies: Reassessing the Transnational Turn (London: Routledge, 2014); Steven Hirsch and Lucien van der Walt, eds., Anarchism and Syndicalism in the Colonial and Postcolonial World, 1870-1940: The Praxis of National Liberation, Internationalism, and Social Revolution (Leiden: Brill, 2010); Davide Turacto, 'Italian Anarchism as a Transnational Movement, 1885-1915,' International Review of Social History 52 (3) (2007), pp. 407-444; Kenyon Zimmer, Immigrants Against the State: Yiddish and Italian Anarchism in America (Champaign-Urbana: University of Illinois Press, forthcoming).

${ }^{70}$ Andrew Hoyt, 'Methods for Tracing Radical Networks: Mapping the Print Culture and Propagandists of the Sovversivi', in Nathan Jun and Jorell Meléndez-Badillo (Eds.) Without Borders or Limits: An Interdisciplinary Approach to Anarchist Studies (Newcastle-upon-Tyne: Cambridge Scholars Publishing, 2013), pp. 76-106, p. 75. 